\title{
Some aspects of reduced disease management against Blumeriella jaapii in sour cherry production
}

\author{
Holb, I.J., Vámos, A., Lakatos, P., Gáll, J.M. \& Abonyi, F. \\ University of Debrecen Centre for Agricultural and Applied Economic Sciences, \\ H-4032 Debrecen, Böszörményi út 138., Hungary, holb@agr.unideb.hu
}

\begin{abstract}
Summary: The aim of this study was to evaluate the effectiveness of reduced spray programmes against cherry leaf spot in integrated and organic sour cherry orchards. Altogether four spray programmes were performed i) standard integrated: sprays followed by forecasting systems during the season, ii) reduced integrated: sprays followed by forecasting systems but only $75 \%$ of the spray numbers used during the season-long spray programme, iii) standard oragnic: sprays applied every 7-14 days during the season and iv) reduced organic: $60 \%$ of the spray numbers used during the season-long spray programme. Our study showed that cherry leaf spot did not increase above 3.1, 7.4, and $8.9 \%$ in 2008, 2009, and 2010, respectively, in the integrated orchards. However, leaf spot incidence was above $20 \%$ in all years in the organic field. Reduced spray programme did not increase significantly cherry leaf spot incidence in the integrated field in either years. However, leaf spot incidence increased significanly (above 20\%) in the reduced spray programme for the organic orchard.
\end{abstract}

Key words: cherry leaf spot, Blumeriella, organic, integrated

\section{Introduction}

Rules and several tools for fungal disease and pest management are well-defined and most of them are successfully implemented for the two environmentally friendly productions systems in apple (e.g. Anon., 2000; Zalom, 1993). Disease and pest management practices in integrated and organic sour cherry production differ markedly from those in conventional production. Synthetic products are restricted in integrated and banned in organic apple production. In integrated fruit production, growers can use only those fungicides which are sorted into 'green' and 'yellow' list of active ingredients by the international and domestic integrated fruit production guidelines. In organic cherry growing, only natural products such as compost, soluble rock powder, sulphur and copper compounds, fungicidal and botanical soaps, traps and biological methods are permitted against fungal diseases and pests according to IFOAM (International Federation of Organic Agriculture Movements) standards (e.g. Anon., 2000), while many synthetic pesticides can be used in conventional cherry production.

Cherry leaf spot (Blumeriella jaapii (Rehm) Arx) significantly reduces profits for sour cherry growers in Hungary in every humid year (e.g. Kaszonyi, 1966; Glits, 1962; Benedek et al., 1990; Pedersen \& Lrschenkohl, 1997; Holb, 2002; Jenser \& Véghelyi, 2003; Holb \& Veisz, 2005; Király \& Szentpéteri, 2006; Holb et al., 2010). Cherry leaf spot causes defoliation by midsummer, which results in soft, poorly colored fruit that are low in soluble solids. Early defoliation delays acclimation of fruit buds and wood to cold temperatures in the fall, increases tree mortality during severe winters, and reduces fruit bud survival and fruit set the following year (Kaszonyi, 1966; Howell \& Stackhouse, 1973; Jenser \& Véghelyi, 2003; Holb \& Veisz, 2005; Holb, 2009). A combination of biological, economic, and regulatory factors puts sour cherry industry in a precarious position regarding disease management. First, the sour cherry cultivar ('Érdi bőtermő', 'Újfehértói fürtös', 'Debreceni bőtermő') which comprises nearly $90 \%$ of sour cherry production in Hungary, is highly susceptible to cherry leaf spot. Sources of resistance have been identified all over the world (e.g. Sjulin et al.,1989; Hrotkó, 1997; Soltész, 1997; Downey, 1999; Apostol, 2000; Wharton et al., 2003; Rozsnyai \& Apostol, 2005; Schuster \& Wolfram, 2005), but resistance has not been incorporated into cultivars that meet the needs of producers. Managing leaf spot in Hungary typically requires five to seven fungicide applications per year, starting at about the time of petal fall and continuing until leaf fall (Jenser \& Véghelyi, 2003; Holb \& Veisz, 2005; Holb et al., 2010).

The aim of our study was to evaulate the effectiveness of reduced spray programmes against cherry leaf spot in integrated and organic cherry orchards.

\section{Materials and methods}

Four reduced fungicide spray programmes were performed in an integrated and an organic sour cherry orchard at Eperjeske, Hungary. The orchard was established in 1997. The two production systems were applied: one following the Hungarian IFP (integrated fruit production) guidelines; and the second following the Hungarian organic production guidelines. The main cultivars of the orchards were 'Érdi bőtermö' and 'Újfehértói fürtös'. The experiment was done on cultivar 'Érdi bőtermő'. The applied fungicides 
in the organic spray programmes were: Champion $50 \mathrm{WP}$, Nordox 75 WG, Olajos rézkén, Kumulus S, and Rézoxiklorid. The applied fungicides in the integrated spray programmes were Score 25 EC, Systane, Folicur Solo, and Rovral.

Altogether four spray programmes were performed two for the integrated and another two for the organic fields in 2008 and 2009. The two integrated spray programmes were: i) standard: sprays followed by forecasting systems during the season, ii) reduced: sprays followed by forecasting systems (according to Eisensmith \& Jones, 1981) but only 75 $\%$ of the spray numbers used during the season-long spray programme. The two organic spray programmes were: i) standard: sprays applied every 7-21 days during the season and ii) reduced: $60 \%$ of the spray numbers used during the season-long spray programme.

At the end of August, incidence of cherry leaf spot on 5 trees was assessed for each treatments. $4 \times 100$ leaves per tree were selected randomly and counted for cherry leaf spot symptoms. Differences among spray programmes of integrated and organic were tested separatelly. Statistaics were performed by ANOVA at $\mathrm{P}=0.05$ level using LSD test.

\section{Results and discussion}

Cherry leaf spot did not incerase above 3.1, 7.4, and $8.9 \%$ in 2008, 2009, and 2010, respectively, in the integrated orchards. However, leaf spot incidence was above $20 \%$ in all years in the organic field (Figures 1-3). Reduced spray programme did not increase significantly cherry leaf spot incidence in the integrated field in either years. However, leaf spot increased significanly (above 20\%) in the reduced spray programme for the organic orchard.

Similar to our results, previous studies showed that integrated control of cherry leaf spot is succesful in susceptible sour cherry cultivars (Jones et al., 1993; Holb et al. 2010). This can be succesfully performed by the use of warning system developed by Eisensmith \& Jones (1981) and Eisensmith et al. (1982a,b) in the early 1980s. The warning system was successfully implemented in the practice and used in integrated cherry production in many cherry growing regions in the United States. The disease warning system indicates low, moderate and severe risk of infection by spores of $B$. jaapii during the whole growing season in order to help fungicide timing of their cherry growers.

Our study clearly demonstrated that leaf spot susceptible cultivars are not suitable for organic growing. The best solution would be leaf spot resistant sour cherry cultivars but only few leaf spot resistant cultivars ('Csengődi' and 'Akasztói') are available (Apostol et al., 2000; Rozsnyai \& Apostol, 2005). For organic cherry production, removal of fallen, infected leaves in autumn can be recommended for reducing leaf spot incidence in the following year $(\mathrm{Holb} \&$ Veisz, 2005). Collected leaves need to be destroyed in order

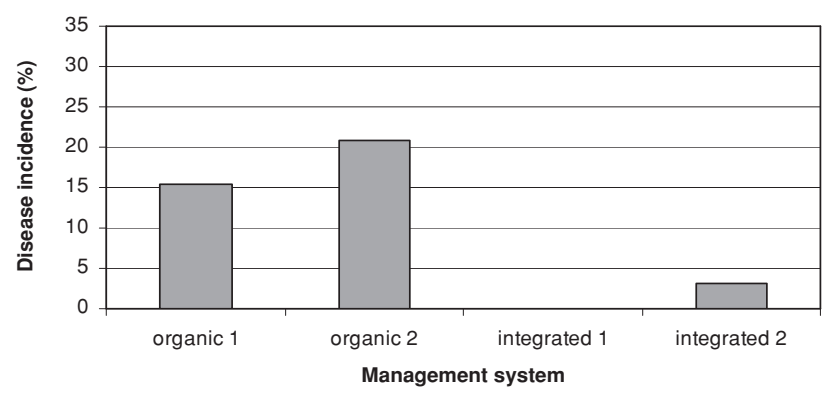

Figure 1: Efficacy of standard and reduced spray programmes on cherry leaf spot on leaf in integrated and organic sour cherry orchards in $2008\left(\mathrm{LSD}_{0.05}\right.$ $=4.8$ - integrated $\operatorname{LSD}_{0.05}=7.6-$ organic $)$.

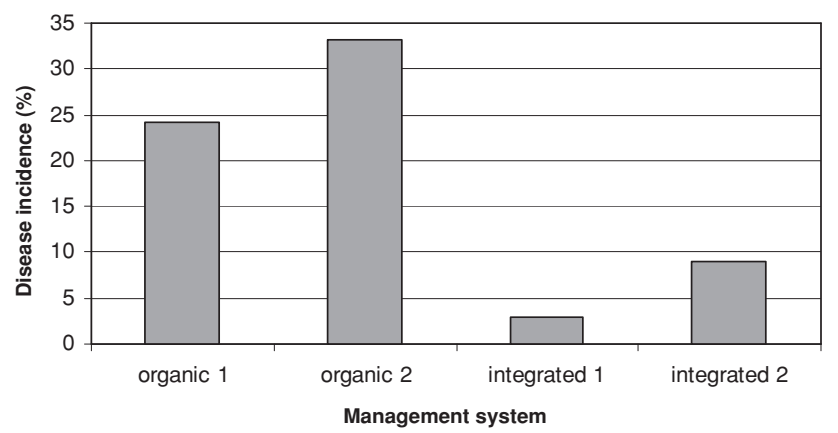

Figure 2: Efficacy of standard and reduced spray programmes on cherry leaf spot on leaf in integrated and organic sour cherry orchards in $2009\left(\mathrm{LSD}_{0.05}\right.$ $=4.8-$ integrated $; \operatorname{LSD}_{0.05}=7.6-$ organic $)$.

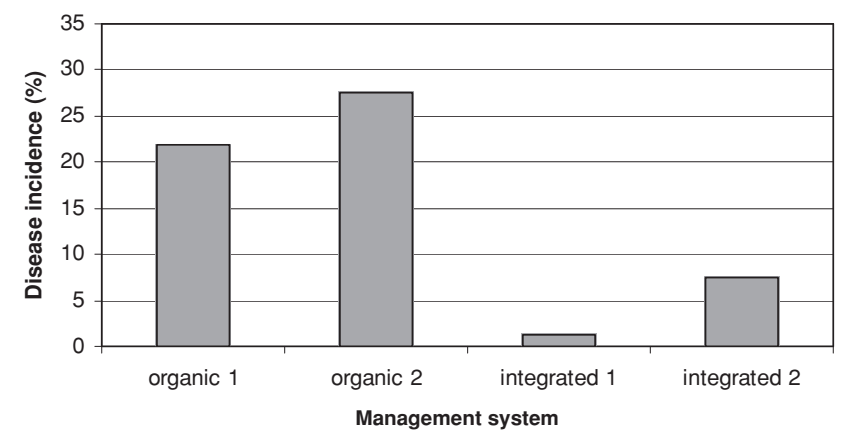

Figure 3: Efficacy of standard and reduced spray programmes on cherry leaf spot on leaf in integrated and organic sour cherry orchards in 2010 $\left(\mathrm{LSD}_{0.05}=4.8-\right.$ integrated; $\mathrm{LSD}_{0.05}=7.6$ - organic $)$.

to avoid overwintering and spore production of the pathogen on infected fallen leaves. In organic production, copper is the only effective compound against the disease which can be used safely only at the begining and at the end of the season against cherry leaf spot (Holb et al., 2010).

\section{Acknowledgements}

The study was supported by the NFÜ programme (TECH 08-A3/2-2008-0373 and by the research programme of OTKA (K 78399) as well as by a János Bolyai Research Fellowship. 


\section{References}

Anonymous (2000): IFOAM Basic Standards for Organic Production and Processing, Tholey-Theley Press, New York, USA.

Apostol, J. (2000): Hungarian resistance breeding in sour cherries. Acta Horticulturae, 538: 363-365.

Benedek, P., Nyéki, J. \& Vályi, I. (1990): Csonthéjas gyümölcsfajták érzékenysége a fontosabb kórokozókkal és kártevőkkel szemben - A fajtaspecifikus növényvédelmi technológia kidolgozása. Növényvédelem 26 (1): 12-31.

Downey, S. (1999): Genetic diversity of Prunus serotina and the evaluation of other wild species for breeding sour cherry resistant to cherry leaf spot. M.Sc. thesis. Michigan State University, East Lansing

Eisensmith, S. P., \& Jones, A. L. (1981): Infection model for timing of fungicide applications to control cherry leaf spot. Plant Disease, 65: 955-958.

Eisensmith, S. P., Jones, A. L. \& Cress, C. E. (1982a): Effects of interrupted wet periods on infection of sour cherry by Coccmyces hiemalis. Phytopathology, 72: 680-682.

Eisensmith, S. P., Sjulin, T. M., Jones, A. L. \& Cress, C. E. (1982b): Effects of age and inculum conentration on infection of sour cherry by Coccmyces hiemalis. Phytopathology, 72: 574-577.

Glits, M. (1962): A cilindrospóriumos betegség hazai előfordulása termőfákon. Kertészet és Szőlészet, 24: 18-19.

Holb, I. (2002): Blumeriellás levélfoltosság. 173-175. In: Radócz, L. (ed.):A héjasok növényvédelme. Szaktudás Kiadóház, Budapest, pp. 256.

Holb, I. (2009): Some biological features of cherry leaf spot (Blumeriella jaapii) with special reference to cultivar susceptibility. International Journal of Horticultural Science, 15 (1-2): 91-94.

Holb I.J., Lakatos, P. \& Abonyi, F. (2010): Some aspects of disease management of cherry leaf spot (Blumeriella jaapii) with special reference to pesticide use. International Journal of Horticultural Science, 16 (1): 45-49.

Holb, I. \& Veisz, J. (2005): A cseresznye és a meggy jelentősebb kórokozói. 138-144. In: Holb I. (ed.): A gyümölcsösök és a szőlő ökológiai növényvédelme. Mezőgazda Kiadó, Budapest, pp. 341.
Howell, G. S., \& Stackhouse, S. S. (1973): The effect of defoliation time on acclimation and dehardening in tart cherry (Prunus cerasus L.). Journal of the American Society forHorticultural Sciences, 98: 132-136.

Hrotkó, K. (1997): Alanyfajták. p. 134-159. In: Soltész M. (ed.): Integrált gyümölcstermesztés. Mezőgazda Kiadó, Budapest

Jenser, G. \& Véghelyi, K. (2003): A cseresznye és a meggy növényvédelme. pp. 259-295. In: Hrotkó K. (szerk.) Cseresznye és meggy. Mezőgazda Kiadó, Budapest, 419.

Jones, A. L., Ehret, G. R., Garcia, S. M., Kesner, C. D. \& Klein, W. M. (1993): Control of cherry leaf spot and powdery mildew on sour cherry with alternate-side applications of fenarimol, myclobutanil, and tebuconazole. Plant Disease, 77: 703-706.

Kaszonyi, S. (1966): Life cycle of Blumeriella jaapii infecting stone-fruit. Acta Phytopathologica Academica Scientia Hungarica, 1: 93-100.

Király, K. \& Szentpéteri T. (2006): Blumeriella jaapii /Rehm/ v. /Arx/ infection of some sweet cherry cultivars in two years with different precipitation conditions. International Journal of Horticultural Sciences, 12 (3): 47-49.

Pedersen, H. L. \& Lrschenkohl L. (1997): Implementation of a warning system to control cherry leaf spot (Blumeriella jaapii) under European conditions. Gartenbauwissenschaft, 62: 197-201.

Rozsnyai Zs. \& Apostol J. (2005): Breeding for sweet and sour cherry disease resistance in Hungary. Acta Horticulturae, 667: 117-122.

Schuster M. \& Wolfram, B. (2005): Sour cherry breeding at Dresden-Pillnitz. Acta Horticulturae, 667: 127-130.

Sjulin, T. M:, Jones A. L. \& Andersen, R. L. (1989): Expression of partial resitance to cherry leaf spot in cultivars of sweet, sour, duke, and European ground cherry. Plant Disease, 73: 56-61.

Soltész, M. (1997): Resistance to pest and diseases. Pages 71-84 in: Integrated Fruit Production. M. Soltész, ed. Mezőgazda Kiadó, Budapest, Hungary. (In Hungarian)

Wharton, P., Iezzoni, A. \& Jones, A. (2003): Screening cherry germ plasm for resistance to leaf spot. Plant Disease, 87: 471-477.

Zalom, F.G. (1993): Reorganizing to facilitate the development and use of integrated pest management, Agric. Ecosyst. Environ., 46: $245-256$. 